Copyright (C) 2015 by Academic Publishing House Researcher

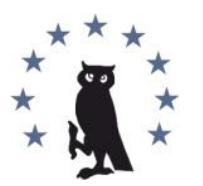

Published in the Russian Federation

European Researcher

Has been issued since 2010.

ISSN 2219-8229

E-ISSN 2224-0136

Vol. 91, Is. 2, pp. 155-162, 2015

DOI: 10.13187/er.2015.91.155

www.erjournal.ru

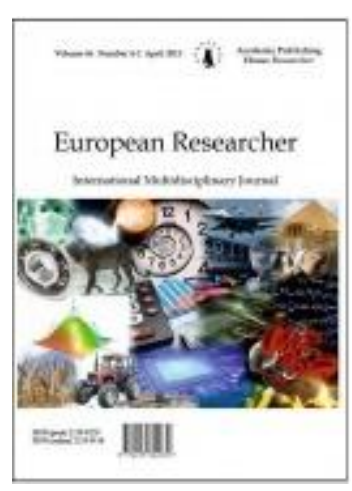

Legal sciences

Юридические науки

UDC 34

\title{
Child Ragpickers in India and Violation of Their Human Rights
}

\author{
Pyali Chatterjee
}

Disha Law College, Raipur, Chattisgarh, India

E-mail: pyali.chatterjee@gmail.com

\begin{abstract}
Rag pickers play an important role in our society. We spread our garbage in the society and these rag pickers use to collect it and send it for recycling. We all know about Child trafficking, child labor and Sexual exploitation of child. Nevertheless, ever we tried to rescue any child who uses to collect these rags from dumping area. Such kind of work done by the children's, amount to violation of their basic human rights. Even though if they were not force by anyone to do such kinds of work but still it will amount to violation of their basic human right. Poverty and illiteracy is one of most common reason behind any kind of violation of human right. In India, any kind of child labors is deal under Child Labour (Prohibition and Regulation) Act, 1986. Here, in this Act certain Occupation and Process are mentioned in the Schedule Part - A and Part - B which is hazardous for the children below 14 years and these includes "rag picking and scavenging" also. In M.C. Mehta Vs State of Tamil Nadu case, the Honorable Supreme Court of India has given certain directions regarding the manner in which children working in hazardous occupations should be shift from such working conditions and they should be rehabilitate. In addition, the conditions of the children who work in the non-hazardous occupations should be improved and regulated by proper law. For "Swach Bharat Abhiyan" not only we have to clean our society but for development of our country, we have to spread literacy also so that our future generation should literate one.
\end{abstract}

Keywords: Child Labor; Rag pickers; Poverty; Illiteracy; Population; Human rights.

\section{Introduction}

According to Freelegal Dictionary*, Rag Pickers means, "a person who picks up rags and other waste material from the streets, refuse heaps, etc., for a livelihood".

International Labour Organization (ILO) ${ }^{\dagger}$ in their recent study estimate that near about 215 millions children in the entire world were involved in some kind of child labor, and more than half

\footnotetext{
${ }^{*}$ http://www.thefreedictionary.com/ragpickers

+ Vinika Koul, Waste of a childhood - poverty stricken child rag pickers, TERRA URBAN https://terraurban.wordpress.com/2012/o6/13/waste-of-a-childhood-poverty-stricken-child-rag-pickers/
} 
of them are even found in their most terrible conditions. It was estimated, that India alone has 17 million child workers - the highest child labor worker in the world. Moreover, UNICEF* in its report mentioned that about 12 percent of children in India aged 5-14 are engaged in child labor activities, including Rag Picking. Even in a recent study, it is found that in Raipur and Patna $20 \%$ of the rag pickers, belong from age group 5-14 years and in most of the dumping site of India especially in Mumbai and New Delhi etc, children's use to work as rag pickers.

In today's world Child labor and Child trafficking has become one of the major social and legal concerns in the entire world. Most of the children start working at a very young age and these children were expose to various forms of exploitation and abuse. Many of these children were engaged in various occupations and processes, which are not dangerous and hazardous for their health but for their life also. Important point to be discussed here is that, it is not possible to calculate the actual number of children working in such process and occupation, as many people employed small children in illegal way, as we know that it is a punishable offence to employed children below 18 years in such occupation and process. Under the Child Labour (Prohibition and Regulation) Act 1986, Children are prohibited to work as rag picking, employed in the carpet weaving, match and fireworks, glass and bangles, lock making, match, slate/pencils, diamond cutting and polishing industries, abattoirs/slaughter houses etc.

It is also found that the main reason behind child labor is unemployment, poverty, illiteracy and population growth. Above all, the one and only reason behind child labor is the poverty, which is the only reason behind any form of exploitation as well as crime.

If we consider Charles Darwin theory, "Survival of the fittest", in cases of Child Rag pickers, then we will find that rag picking becomes the source of earning for the poor children off course for their survival. As money is an important thing to survive in this world.

\section{Child ragpickers}

Society has not only failed to protect the children from becoming child rag pickers also, they were not treated well.

Most of the poor children, between five to eighteen years of age, earn their livelihood by polishing shoes, washing cars, finding parking spaces, rag picking, etc and their average earnings vary between Rs 15 to 20 per day depending on the nature of the works. And these children can be found easily near bus stand, railway station, movie hall etc fighting for their survival.

Sometimes children were forced to become rag pickers by the rag purchaser and some time the children choose to become rag pickers by themselves as independent. And from here the journey of their exploitation, engagement with criminals, drug addiction began, which is neither good for their development and nor for the society where they are living.

Any form of child labor should be abolished as these not only harm the children but its harm the entire society. A country will develop only when its future generation will be safe and protected. And for this purpose certain basic rights are granted to all children i.e. decent living; right to education; right to protection against exploitation. But it has been found that there rights were violated due to many reason. And only because of these reason Rag picking and Scavenging was included in Part-B of the Child Labour (Prohibition and Regulation) Act 1986 as one of the Prohibited processes for employment of children who have not completed 14 years of age to protect children from exploitation.

\section{Reason behind child rag picker}

Many authors, researchers, NGO etc have done great work to find out the reason behind children working as rag pickers. And the most common reason found by them behind it, is poverty. The following are some work done by the researcher on the issue of Child rag pickers and their findings-

Kamat $^{\dagger}$, in his article "Ragpickers of India" states that most of the Rag picking Children are extremely poor, illiterate and belong to rural immigrant families and most of their families are in need of extra income from these young children.

\footnotetext{
* Ibid.

${ }^{\dagger}$ http://shodhganga.inflibnet.ac.in/bitstream/10603/8069/7/07_chapter\%202.pdf
} 
Again Tripathy and Pradhan" in their work "Girl Child in India" explains the problem of child labour which includes both male and female and their condition in a hazardous occupation of rag picking in Berhampur town (Orissa). In their work they mentions about the family size of girl child rag pickers. The girl child rag pickers family size is more than 6 persons.

$>$ Balkumar etal had done study on the family of child rag pickers of Nepal in their work "Nepal -Situation of Child Rag pickers: A Rapid Assessment" ${ }^{\text {. }}$ The authors conducted a survey of 300 children ages between 5-17 years who worked as rag pickers in six major municipalities. The average family size of child rag pickers is 5.4 members, which is slightly higher than the national average of 5.1. The girl rag pickers usually come from larger families (6.3) than boys do (5.2). This assessment shows that the large majority $60.3 \%$ of children interviewed have both parents (own or biological father or mother) only few are belonging to families with a step parent or single parent or no parents. In their assessment, three indicators were chosen to determine the economic background of the child rag pickers. Over 2/3 of respondents (68\%) indicated that their family owned home. The majority of child rag pickers families (54.7 \%) do not own farmland. The main occupation among families of rag pickers is of a non-agricultural nature, which may include small business, mechanical work etc and the money paid for it is also very low. And some of the family members worked as rag picking.

$>$ Again in another study conducted by Mita Bhadrain" "Girl Child in Indian Society" reveals that most of the girl who worked as rag pickers belongs to very poor families and they are illiterate also. Their parents are mostly landless labours or small land labours and most of them live in slums. Most of the children are belonging to Schedule Caste and Schedule Tribes families.

$>$ Even Kshitij§ (A Project for the Child Rag pickers of Bhandewari Dumping Ground, Nagpur) reveals that rag pickers are sizable proportion among the poorest workers in the urban informal economy. The traditional beggars have opted for rag picking. Most of the rag pickers are extremely poor, illiterate and belong to immigrant families. Their families need supplementary income.

$>$ Rag pickers ${ }^{* *}:$ Scavengers at a Different Graveyard, A Documentary on The Rag pickers of Mumbai explore the life of rag pickers and found that majority of them are below the poverty line and socio-economic strata and live a difficult life.

$>\mathrm{Rai}^{++}$in his work "Child Labour: A Reality" done research on the family of rag pickers children and found that most of the children lived in urban areas and they are mostly street children and work in the streets. And most of them had no relation with their families.

Again in another survey conducted by a NGO"* in 1990 "Agape, Bangalore" found that rag pickers come from violent and broken homes, perhaps second marriages where the mother has been burnt to death with kerosene, the father demanding further dowry from the wife's family to feed his drunkenness. The children from the first marriage not wanted, beating, starvation and deprivation of security and love are daily occurrences. Some are forced from a very young age to work and earn money, a few are influenced by peer pressure, and some are orphans fighting a daily battle to survive. Boys unable to tolerate the daily beatings and dysfunctional family life run away and become street children. Girls are forced to look after younger family members even have to beg for their own survival and that of the younger child. They are treated as slaves in the home and many are forced into prostitution at a very early age.

Again Singh ${ }^{\S}$ in his book "Child Labour" has broadly categorized Rag pickers into 3 groups, based on their contact with their families: i) Children who will be living with their families. Whether it be on the street, in slums, or waste land or abandoned building etc. but would be spending a lot of time working or hanging about on the streets. It has been estimated that this will be the largest of the three categories. ii) Children who would be living and working on the

\footnotetext{
* Ibid.

${ }^{\dagger}$ Ibid.

* Ibid.

$\S$ Ibid.

${ }^{* *}$ Ibid.

${ }^{+\dagger}$ Ibid.

\#\# Ibid.

$\S \S$ Ibid.
} 
street with occasional family contacts. These children, sometimes, send money to their families. They consider the streets as their homes. iii) Children who would be having no family contact what so ever. These children will be either orphaned abandoned or neglected by, or strange from their families. Psychologically, they are deprived of love, affection and sympathy of a family.

> Again Rita Pannikka* in her Study conduct on Street Girls in the Union Territory of Delhi mentioned about her case study of street girl children. In that case study she found that, the youngest of four daughters of a family in which the father work as a rag picker and his girl too picks up rags and adds family income. Due to their family circumstances she is forced to do work which she does not personally like. From a favorite child she has become a working child without any protest, toiling for nearly 16-18 hours a day. Recently she has been engaged to an illiterate farmer boy and expects that her future husband would help her in her sorrows. She wishes to have a house of her own with good environments where she would not see rags. She also wants to learn tailoring to wear new clothes of her liking.

Thus, from the above discussion we found that large family, neglected children, poverty, low income of family etc are the main reason for the small children to work as rag pickers, whether willingly or not it does not matter.

As it is, clear now that Poverty is the root cause of child labour, and education is the only fundamental to overcome the poverty trap. As Oxfam states, "Education is the best escape route from a life of poverty. Education brings with it improved health, the chance of prosperity, and hope for the future. It opens the door to a life of dignity and independence." ${ }^{\dagger}$ It is important for the parents to understand the importance of primary education which is the only way to break the cycle of poverty. And only because of this reason free primary education was included under Article 26 of the Universal declaration of Human Rights. Even Principle 7 of the UN Declaration on the Rights of the Child, and Article 28 and 29 of the UN Convention on the Rights of the Child, states that primary education should be universal and free for all.

\section{Guidelines of supreme court}

In the M.C. Mehta Vs State of Tamil Nadu AIR 1991 S.C. $417^{\ddagger}$, the Honorable Supreme Court of India has given certain directions regarding the manner in which children working in hazardous occupations should be shift from such working conditions and they should be rehabilitate. In addition, the conditions of the children who work in the non-hazardous occupations should be improved and regulated by proper law. The following are the direction:

1. Withdrawal of children working in hazardous industries and ensuring their education in appropriate institutions;

2. Contribution of Rs 20,000 per child to be paid by the offending employers of children to a welfare fund to be established for this purpose;

3. Employment to one adult member of the family of the child so withdrawn from work, and if that is not possible, a contribution of Rs 5,000 to the welfare fund to be made by the State Government;

4. Financial assistance to the families of the children so withdrawn to be paid out of the interest earnings on the corpus of Rs 20,000/25,000 deposited in the welfare fund, as long as the child is actually sent to school;

5. Regulating hours of work for children working in non-hazardous occupations so that their working hours do not exceed six hours per day, and education for at least two hours is ensured.

\section{Indian law for the protection of child rights}

To protect children below 18 years from exploitation and child labor, the Indian Government has formed many constitutional provisions for their protection as well as for their development. The following are the constitutional provisions:

\footnotetext{
* Ibid.

‘ Eve Naftalin, Report For Span On The Human Rights' Violations Of The Ragpicker Children, http://www.streetchildrenresources.org/wp-content/uploads/2013/o3/human-rights-violationsragpickers.pdf

* Jyoti Angrish, CHILD LABOUR IN INDIA-PRESENT SCENARIO, Legal India

http://www.legalindia.in/child-labour-in-india-present-scenario/
} 
1. According Article $24^{*}$, of Indian Constitution, "No child below the age of 14 years shall be employed to work in any factory or mine or engaged in any other hazardous employment".

2. Again under Article 39( e) ${ }^{\dagger}$ of Indian Constitution, "The State shall in particular, directs its policy towards securing- that the health and strength of workers, men and women and the tender age of the children are not abused and that citizens are not forced by economic necessity to enter vocations unsuited to their age or strength".

3. Again under Article 39(f) $)^{\ddagger}$ of Indian Constitution, "The State shall in particular, directs its policy towards securing- that Children are given opportunities and facilities to develop in a healthy manner and in conditions of freedom and dignity and that childhood and youth are protected against exploitations and against moral and material abandon."

4. Again under Article $45^{\S}$ of Indian Constitution, "The state shall endeavor to provide, early childhood care and education for all children until they complete the age of 6 years".

5. Again under Article $21 \mathrm{~A}^{* * *}$ of Indian Constitution, "The state shall provide free and compulsory education to all children between the ages of six to 14 years in such a manner as the state may by law determine."

6. Again under Article $51 \mathrm{~A}(\mathrm{k})^{\dagger \dagger}$ of Indian Constitution, "Who is a parent or guardian to provide opportunities for education to his child or, as the case may be, ward between the age of six and14years".

Apart from the above constitutional provision, the following are the other laws framed for the development and protection of the children in India ${ }^{\ddagger *}$ :-

1. The Apprentices Act, 1861

2. The Child Labour Act, 1986

3. The Child Marriage Restraint Act, 1929

4. The Children (pledging of labour) Act, 1929

5. Children Act, 1960

6. The Guardian and Wards Act, 1890

7. The Hindu Minority and Guardianship Act, 1956

8. The Hindu Adoption and Maintence Act, 1956

9. The Immoral Traffic (Prevention) Act, 1956

10. Juvenile Justice Act, 1986

11. The Orphanages and other charitable Homes (supervision and control) Act, 1960

12. Probation of offenders Act, 1958

13. Reformatory schools Act, 1857

14. The women's and children's institutions (licensing) Act, 1956

15. The young persons (Harmful publications) Act, 1956

When these small children unable to avail their basic rights granted by Indian Constitution as well as in The Universal Declaration of Human, will amount to be a violation of their Human rights.

\section{Gurupad swamy committee ${ }^{\S \S}$}

The Government of India in the year 1979 formed the first committee called Gurupad Swamy Committee to study the issue of child labor and to suggest measures to handel it. The Committee examined the problem in detail and made some recommendations. It observed that as long as poverty continued, it would be difficult to eliminate child labor and hence, any attempt to abolish it through legal recourse would not be a practical solution. The Committee felt that in such circumstances, the only alternative left was to ban child labor in hazardous areas, to regulate, and to improve the conditions of work in such areas. It recommended that a multiple policy approach

\footnotetext{
${ }^{*}$ O.P. RAI, THE CONSTITUTION OF INDIA,40 (Orient Publishing Company, $2^{\text {nd }}$ ed. 2014)

${ }^{\dagger}$ Ibid. at $49-50$

₹ Ibid.

$\S$ Ibid. at 50

** Ibid. 37

${ }^{+1}$ Ibid at 52

${ }^{\text {\# }}$ Supra note. 15

$\S$ Supra note. 15
} 
was required in dealing with the problems of working children. Based on the recommendations of Gurupad Swamy Committee, The Child Labour (Prohibition and Regulation) Act, 1986 was passed. And after this Act, employment of children below the age of 14 was prohibited in factories, mines and in other forms of hazardous employment, and regulates the working conditions of children in other employment. Sec.3 of this Act imposes prohibition on employment of children in dhabas, restaurants, hotels, motels, tea shops, resorts, spas or other recreational centre's etc. Recently, child labour is totally banned by the government with free education and other facilities to the child upto the age of 14 .

\section{International law on child labour*}

Article 25 (2) Of UN declaration of Human Rights, says that children required special care and assistance. The International Covenant on Civil and Political Rights under Articles 23 and 24 and the International Covenant on Economic, Social and Cultural Rights under Article 10 made provisions for the care and protection of the child. However, the International Labour Organization (ILO) provides universal standards and guidelines. The ILO, is a specialized agency of the UN, aims to provide guidance and standards for labour practices around the world. The International Convention and other international instruments, which deal with the subject of child labour are as follows:

1. Convention on the Rights of the Child, 1989

2. Worst Form of Child Labour Convention, 1999; and

3. Worst Form of Child Labour Recommendation

The International Program on the Elimination of Child Labour (IPEC) is a global program launched by the International Labour Organization in December 1991. India was the first country to join it in 1992 when it signed a Memorandum of Understanding (MOU) with ILO. The MOU that expired on 31.12.1996 has been extended from time to time and has recently been extended till 31st December, 2006. The long-term objective of IPEC is to contribute to the effective abolition of child labour. IPEC-India has, during the period 1992-2002, supported over 165 Action Programs.

The Govt. of India and the US Department of Labour have also initiated a US\$ 40 million project aimed at eliminating child labour in 10 hazardous sectors across 21 districts in five States namely, Maharashtra, Madhya Pradesh, Tamil Nadu, Uttar Pradesh and NCT of Delhi. This project was popularly known as INDUS and was implemented by ILO. An estimate of 80,000 children will be withdrawn and rehabilitated through this project. Also Support activities will be provided to 10,000 families of former child workers. On 20 November 2009, the global community celebrates the 2oth anniversary of the adoption by the United Nations General Assembly of the Convention on the Rights of the Child, the unique document that sets international standards for the care, treatment and protection of all individuals below age 18 .

\section{Health issue related to child rag pickers ${ }^{\dagger}$}

From the above discussion we have find that most of the rag pickers belongs to poor society. And they were also illiterate. It is found that while collecting rags sometimes they are subjected to chemical poisons and infections. The rag pickers are very prone to diseases like tuberculosis and cancer due to their exposure to hazardous materials. The children sometime while collecting rags from the garbage dumps comes in contact with rags which are toxic, corrosive, flammable, explosive, etc. And these substances are hazardous in nature. Bio- Medical waste, such as needles, syringes, old medicines and soiled bandages etc are very dangerous to the children who pick them up from the garbage dumps and can cause HEPATITIS A and B, Skin Diseases etc. And some of hazardous waste is so poisonous, that even by touching them it can get into the body and cause cancer or other diseases e.g. rat poison and pesticides. But this kind of waste generally contain picture of a skull on the container which is a sign of danger, but children due to their illiteracy fail to understand the meaning of such danger sign in the container suffered serious health issue while collecting rags from such areas.

\footnotetext{
* Ibid.

K.L.Kamat, Rag Pickers of India, http://www.kamat.com/kalranga/people/rag_pickers/
} 
Here one thing which is necessary to mention here that Right to health is a basic human right. But what about the rights of this children, who works as rag pickers.

\section{Suggestion}

Government of India has already framed so many laws for the protection of the Child that no other new law is required. But what is required is the implication of the existing laws in strict ways for the benefit of the poor children. Following are some suggestion:

- NGO can play an important role by rehabiliting the street children who work as rag picker. And also by spreading awareness of the various Government scheme for the poor children like midday meal in school etc.

- Government should establish more shelter home for the poor children so that they can be prevented from becoming child labour and also from any other crime, which will harm their moral and over all development.

- Media can also spread messages through various shows about the government scheme for the poor families.

- Growing Population is also one of the main causes for the increase of the poverty. So population growth is also to be checked by explaining the advantages of family planning methods.

- Government should bring more employment scheme for the families belonging from the backward classes.

- Even NGO can spread awareness among the child rag pickers about the various impact of hazardous rags to their health by educating them and also making them aware by defining the meaning of various symbols drawn in the plastics bags, container e.g. Biomedical Hazards Symbols. in villages.

- Government can provide employment opportunity by promoting small scale industries etc

- Government should try to improve the Government Schools condition of the villages.

- Government should provide vocational training to street children for their betterment.

- Free medical camp should be organized for the street children's and children who are living in slums areas for their regular check up.

- Families living in slum areas should be informed about the various schemes of the government relating to their development as well as for their children with the help of the NGO and media.

- Government should formed strong machinery to promote and facilitate all the government polices to the poor people and the children.

- And lastly but not the least anybody who find any children working as a child labour should immediately call the child help line number 1098 for the protection of the children.

IF I TRY, THEN ONLY OTHERS WILL TRY TO SAVE THE FUTURE GENERATION OF INDIA

\section{Conclusion}

The development of the country depends on the development of the future generation i.e. children. If the children did not develop physically and mentally in that case the growth of the country will also decrease. Government should try to bring new schemes for the development of the inferior part of the society. So that, no children will become rag pickers or become the victim of trafficking etc. Once the poverty from the society erased, then automatically all problems related to this will be finished. So, for the benefit of the country, poverty should be eradicated first. As this is one of the major causes behind any crime, exploitation etc. And then only the Country will progress.

\section{References}

1. http://www.thefreedictionary.com/ragpickers

2. Vinika Koul, Waste of a childhood- poverty stricken child rag pickers, TERRA URBAN https://terraurban.wordpress.com/2012/o6/13/waste-of-a-childhood-poverty-stricken-childrag-pickers/

3. http://shodhganga.inflibnet.ac.in/bitstream/10603/8069/7/07_chapter\%202.pdf 
a. Eve Naftalin, Report For Span On The Human Rights' Violations Of The Ragpicker Children,http://www.streetchildrenresources.org/wp-content/uploads/2013/o3/human- rightsviolations-ragpickers.pdf Jyoti Angrish, CHILD LABOUR IN INDIA-PRESENT SCENARIO, Legal India http://www.legalindia.in/child-labour-in-india-present-scenario/ O.P. RAI, THE CONSTITUTION OF INDIA, 40 (Orient Publishing Company, $2^{\text {nd }}$ ed. 2014) K.L.Kamat, Rag Pickers of India, http://www.kamat.com/kalranga/people/rag_pickers/

4. Mamta Rao (2013). Constitutional Law 268-269. Abhinandan Malik, 1st ed.

5. V.N.Shukla, "Constitution of India", (Lucknow: Eastern law Company, 2006)

6. RAG PICKERS IN INDIA: NOT PAINTING A GOOD PICTURE, Millennium India Education Foundation, http://mief.in/rag-pickers-in-india-not-painting-a-good-picture/

7. Michael Simon, INDIA'S SLUMDOG RAGPICKERS, July 6, 2010

8. http://18oorecycling.com/

9. PRIMARY EDUCATION FOR RAGPICKER`S CHILDREN, IPCA http://www. ipcaworld. co.in /pages.aspx?pYkq5e\%2FuIrDbfyyJw2LK2w\%3D\%3D

10. A FAMILY'S LIFE RAG-PICKING IN NEW DELHI: 'I DO NOT WANT MY CHILDREN

TO DIE IN THIS TRASH', Fox News, December 01, 2014

11. http://www.foxnews.com/world/2014/12/o1/family-life-rag-picking-in-new-delhi-donot-want-my-children-to-die-in-this/

12. The problems of street children, i.india

13. http://www.i-indiaonline.com/sc_crisis_theproblem.htm

14. Shishir Srivastava, RAGPICKERS IN MODERN DAY INDIA, merinews, June 2, 2008

15. http://www.merinews.com/article/rag-pickers-in-modern-day-india/135059.shtml 